\title{
A Correlational Study on Medical Parasitology Practical Work and Students' Achievement on Parasitology Materials on the Final Exam
}

\author{
Fitria Siwi Nur Rochmah ${ }^{1}$, Novyan Lusiyana ${ }^{1 *}$ \\ ${ }^{1}$ Department Parasitology, Faculty of Medicine, Universitas Islam Indonesia \\ *Corresponding author. Email: $107110411 @$ uil.ac.id
}

\begin{abstract}
Background and aims: Parasitology practical work is expected to strengthen the retention of parasitology materials for medical students in block of adult problems. The aim of this study was to determine the correlation between the laboratory assessment and the achievement of parasitology materials on final exam in block of adult problems. Methods: This is a cross sectional study using secondary data of some classes of medical students in block of adult problems, which comply with the inclusion criteria. The data were divided into laboratory assessment score and achievement of parasitology materials on block of adult problems in the final exam. The achievement of parasitology materials on final exam was counted from the average true answer for all questions, divided by all parasitology questions. The data were analyzed for the normality and median value. A descriptive analysis, Spearman correlations test, was performed to find out the correlation between laboratory assessment and parasitology materials in block of adult problems. Results: The data of laboratory assessment score and achievement of parasitology materials which fulfill the criteria were on 2015's and 2017's class. The median score of both data on each class were (75.75; 71.43) and $(61.75 ; 50)$ with normality test score of $p>0.05$. The median score of practical work on 2015 's was higher than that of 2017's class. The Spearman rank test between the 2 parameter on 2017's and 2015's class showed that the laboratory assessment and achievement of parasitology materials in final exam were not related ( $\mathrm{p} \geq 0.05$ ). Conclusions and Recommendation: There was no correlation between the laboratory assessment and the achievement of parasitology materials on the final exam in block of adult problems. Thus, it is necessary to improve students' achievement on parasitology materials was. Some factors to influence the retention of students' knowledge on parasitology should be evaluated as the basis to improve the learning methods.
\end{abstract}

Keywords: parasitology, practical, correlation

\section{INTRODUCTION}

Parasitology, a branch of medicine, is a study about parasitic organism that causes parasitic diseases in human. Medical parasitology learns about taxonomy, morphology, epidemiology, life cycle, and pathology of the diseases. The Indonesian standards for Medical Doctor Competency (SKDI) showed that many parasitic diseases are in the $4^{\text {th }}$ level of competency. In other words, doctors are required to be capable of diagnosing and treating parasitic diseases. The medical students would be able to diagnose the parasite correctly if they can identify the morphological feature of parasites. The parasite morphology is not only learned theoretically at the higher education institutions but also practically in the practical work. In the practical work, the parasite morphology is learned by microscopic identification.
Practical work in parasitology contains some activities to practice microscopic skill to identify the parasite slides. The identification process in practical work will employ a stronger long-term memory. Practical-work-based learning is known to improve cognitive and psychomotoric abilities, as supported by the theory.[1] The morphological theory is delivered by lectures. The parasitology curriculum for medical students in the faculty of medicine, Universitas Islam Indonesia is provided in the second-year and third-year. The practical work is expected to strengthen student's understanding in parasitology.

The learning process in Practical work in parasitology encompasses pre-test, introductory lecture, observing slides, and post-test. The practical work learning series ends with a final test on practical work known as laboratory assessment. The materials on practical work are also re-tested in the final exam, including the 
materials on block of adult problems. Thus, it is necessary to evaluate students' achievement based on parasitology learning objectives in practical work with their achievement on final exam, especially for the materials related to the block of adult problems. Evaluation of students' achievement on practical work in parasitology for the materials related to in this block will be a reference for arranging the learning activities for parasitology department, especially in practical work.

\section{METHODS}

This study has received ethical approval from the Research Ethic committee, faculty of medicine, Universitas Islam Indonesia with the number 11/Ka.Kom.Et/70/KE/XII/2020.

This is a cross sectional study using secondary data on block of adult problems. The block was conducted in the curriculum for third year students. The parasitology materials that are taught in this block are about morphological identification of arthropods. This study used the data of the third-year students of 2015's and 2017's class of medical students who comply with the inclusion criteria. The data of block adult problems of 2016's class was excluded because of inadequate information on the data. The inclusion criteria were medical students who took subjects in the block of adult problem; first time following this block; and having completed the data for the practical work and final exam block.

The data were divided into laboratory assessment and students' achievement on parasitology materials on final block exam. The students' achievement on parasitology materials on final exam was calculated from the average true answer of all question, divided by all parasitology questions.

Data were analyzed descriptively using SPSS. The data were presented in percentages. A descriptive analysis and Spearman correlations test were performed to find out the correlation between parasitology laboratory assessment and students' achievement on parasitology materials on block of adult problems.

\section{RESULT}

The data of practical work and students' achievement on parasitology materials, which met the criteria were the 2015's and 2017's classes. The median score of both data on each class were $(75.75 ; 71.43)$ and $(61.75 ; 50)$ with normality test score of $\mathrm{p}>0.05$. The median score of practical work on 2015's was higher than that of 2017's class. The Spearman rank test between the 2 parameter on 2017's class revealed that the practical work and students' achievement on parasitology materials in the final exam were not related ( $\mathrm{p} \geq 0.05$ ).
Table 1. Medical Students' Achievement in Adult Block

\begin{tabular}{|c|c|c|c|c|c|}
\hline \multirow[b]{2}{*}{ Class } & \multicolumn{2}{|c|}{ Practical work } & \multicolumn{2}{|c|}{ Final exam } & \multirow{2}{*}{$\begin{array}{l}\text { Spearman } \\
\text { rank test }\end{array}$} \\
\hline & Mean & $\begin{array}{c}\text { medi } \\
\text { an }\end{array}$ & Mean & $\begin{array}{c}\text { media } \\
\mathrm{n}\end{array}$ & \\
\hline $\begin{array}{c}2015 \\
\text { (n 173) }\end{array}$ & 75.95 & 75.75 & 74.24 & 71.43 & $\mathrm{p}=0.05$ \\
\hline $\begin{array}{c}2017 \\
\text { (n 144) }\end{array}$ & 60.18 & 61.73 & 53.71 & 50 & $\mathrm{p}=0.686$ \\
\hline
\end{tabular}

Table 2 presented students' achievement on parasitology material in the final exam on block of adult problem. The number of students who scored more than 60 in 2015's class was higher (74\%) than those in 2015 's class $(36 \%)$.

Table 2. The achievement of parasitology materials in the final exam.

\begin{tabular}{lll}
\hline Class & Score $<60$ & Score > 60 \\
\hline $2015(\mathrm{n} \mathrm{173)}$ & $45(26 \%)$ & $128(74 \%)$ \\
\hline $2017(\mathrm{n} \mathrm{144)}$ & $91(63.2 \%)$ & $53(36.8 \%)$ \\
\hline
\end{tabular}

\section{DISCUSSION}

Parasitology, biomedical practical work, is the supporting learning activities through direct observation.[2] In this activity, students are expected to be assisted in identifying parasite morphology for correct diagnosis of parasitic diseases. Students' achievement on practical materials can be seen in laboratory assessment score and the final block exam.

However, students' achievement on practical work materials in the final exam has not shown satisfactory result. This disconcerting result was attributed to some factors not only from the student's individual aspects,[3] but also from the learning method, teachers, materials, and environment.[2],[4] Previous studies stated that students' achievement on final exam was influenced by the level of difficulties of the materials.[5] Practical work conducted at FK UII generally applied a conventional method. The practical work in parasitology usually begin with a pre-test taken from the module on practical work, followed by short explanation from the lecturer, observation of the parasite slide on microscope with assistant in a small group, and ended with a post-test. In parasitology practical work, students are normally grouped into some large groups. This method serves as an essential process, but should be combined with other method.[6]

The modified practical method not only increases the quality of practical work, but also enhances the knowledge retention of the students.[2] Several practical works had been developed in some research models, such as problem solving laboratory. This method demonstrated the improving quality of practical work after the application of the model. Problem solving laboratories were carried out by triggering problems based on the provided concepts. The students would solve these problems and at the end of the practical work, they would be required to present the problems.[7] 
Another learning model on practical work was blended learning. The experiment using this method showed that the student retention and attention on the practical work materials were higher than that using conventional model of practical works.[8] This study also showed that students not only had better comprehension on practical work materials, but also applied more effective procedure in the practical work.[3] The blended learning in this study mixed the micro-video and hands on learning method. The micro video not only replaced the manual practical work but also introduced the lecture materials as shown in other study.[2]

Practical work in parasitology was provided to undergraduate students in medical faculty as the basis for strengthening the understanding of biomedical science.[2] The parasitical diseases to study in block of adult problem were scabies, insect bite, and pediculosis. The morphological identification of those arthropode was conducted in small-group discussion with assistants. The application of small-group case presentation exercise was proven to be more focused, interactive, and led to the development of concepts or principles.[6] The practical work assistant only assisted the medical students to understand the practical work materials as explained in other studies. The other study showed that the students' achievement on practical work accompanied by assistants was better than that without assistants. [9]

A good practical work method will improve the learning quality of students.[2] Factors to influence students' achievement in practical work were students' perception on practical work, their readiness, motivation, satisfaction with lecturers or assistant, and their practical work method. Students should improve their learning techniques by applying some other approaches, such as elaborative interrogation, self-explanation, summarization, highlighting, practice testing, and distributed practice.[10]

\section{CONCLUSION}

The data indicates that those factors should be evaluated in the practical work in parasitology in block of adult problems. The evaluation result of practical work method, student satisfaction, and material analysis on students' achievement could be the basis for better application of alternative learning method in practical work.

\section{AUTHORS' CONTRIBUTIONS}

FSNR is a chief contributor who is responsible for the concept, research path, and analysis of the results. NL is a supporting contributor who is responsible for the data analysis, data interpretation, and preparation for the result and discussion.

\section{ACKNOWLEDGMENTS}

The researchers would like to express gratitude to the academic staffs, Faculty of Medicine, Universitas Islam Indonesia for their contribution in the data collection of this research.

\section{REFERENCES}

[1] S. Murti, Muhibuddin, and C. Nurmaliah, "Penerapan Pembelajaran Berbasis Praktikum Untuk Peningkatkan Kemampuan Kognitif Dan Psikomotorik Pada Perkuliahan Anatomi Tumbuhan," J. Biol. Edukasi, vol. 6, no. 1, pp. 18, 2014.

[2] S. M. Jones and A. Edwards, "Online prelaboratory exercises enhance student preparedness for first year biology practical classes," Int. J. Innov. Sci. Math. Educ., vol. 18, no. 2, pp. 1-9, 2010.

[3] I. Abrahams, "Does Practical Work Really Motivate? A study of the affective value of practical work in secondary school science," Int. J. Sci. Educ., vol. 31, no. 17, pp. 2335-2353, 2009.

[4] Kaylene and Caroline C. Williams, "Five key ingredients for improving student motivation," Res High Educ J, vol. 12, pp. 1-23, 2011.

[5] R. Preston, M. Gratani, K. Owens, P. Roche, M. Zimanyi, and B. Malau-Aduli, "Exploring the Impact of Assessment on Medical Students' Learning," Assess. Eval. High. Educ., vol. 45, no. 1, pp. 109-124, 2020.

[6] J. Kulkarni, B. Tamang, and P. Sinha, "The impact and significance of small and large group teaching and learning in medical curriculum," SMU Med. J., vol. 2, no. 2, pp. 175-183, 2018.

[7] Elianawati and B. Subali, "Penerapan Model Praktikum Problem Solving Laboratory," $J$. Pendidik. Fis. Indones. 6 90-97, vol. 6, pp. 9097, 2010.

[8] J. Chen et al., "Blended learning in basic medical laboratory courses improves medical students' abilities in self-learning, understanding, and problem solving," Adv. Physiol. Educ., vol. 44, no. 1, pp. 9-14, 2020.

[9] S. D. Lesmana and E. Maryanti, "Modifikasi Sistem Asistensi dan Responsi Kelas Kecil pada Praktikum Parasitologi Blok Digestif dan Hematoimunologi," JIK, vol. 1, pp. 46-51, 2014.

[10] J. Dunlosky, K. A. Rawson, E. J. Marsh, M. J. Nathan, and D. T. Willingham, "Improving Students ' Learning With Effective Learning Techniques: Promising Directions From Cognitive and Educational Psychology," Psychol. Sci. Public Interes., vol. 14, no. 1, pp. 4-58, 2013. 